\title{
CONSTRUCTION LABOUR PRODUCTIVITY ON CAMPUS PROJECT IN PALEMBANG, INDONESIA
}

\author{
Revianty Nurmeyliandari Nurhendi ${ }^{1}$, Muhamad Azry Khoiry ${ }^{2}$, Noraini Hamzah ${ }^{3}$ \\ ${ }^{1,2,3}$ Department of Civil Engineering, Faculty of Engineering \& Built Environment, Universiti Kebangsaan Malaysia, Bangi, \\ Malaysia. \\ ${ }^{\text {I} P r o g r a m ~ S t u d i ~ T e k n i k ~ S i p i l, ~ F a k u l t a s ~ T e k n i k, ~ U n i v e r s i t a s ~ B i n a ~ D a r m a, ~ P a l e m b a n g, ~ S u m a t e r a ~ S e l a t a n, ~ I n d o n e s i a 2 ~}$ \\ Iazrykhoiry@ukm.edu.my
}

\begin{abstract}
Contruction labour productivity has relationship to determine the successful implementation of the construction project schedule. By looking at the importance of labour productivity in construction projects, this study aims to analyze labour productivity in construction projects on one campus in the city of Palembang, Indonesia. The campus is Universitas Islam Negeri Raden Fatah Palembang. This research method is work sampling method. Observations of work activities carried out paying attention to periods of time, namely during and after the month of Ramadan. The result show labours do work effectively, but construction labour productivity still needs to be improved, especially in flooring and scafolding works. This research also consludes labour productivity in months other than Ramadan is higher than labour productivity during Ramadan.
\end{abstract}

Keyword: construction, labour, productivity

\section{Introduction}

Construction sector has a significant affect in the development of any nation (Durdyev and Ismail, 2012). Ofori (2019) stated relationship between construction and development. Construction contributes greatly to national socioeconomic development by building productive infrastructure and facilities. By making a significant contribution to the national economy each period, construction is a major sector in the economy. in addition, one of the most important things from the contribution of the construction sector is creating jobs because of its nature as a labour-intensive sector. In all countries contraction is one of the mainstays of the economy which can transfer technology to all citizens and create an entrepreneurial climate.

In Indonesia, the construction sector has contributed to the economic growth rate of around 5\% (Khurriah and Istifadah, 2019). Going forward, the construction sector will greatly contribute because it can reduce infrastructure deficits in terms of both availability and quality. For example, when in the last 20 years only 200 kilometers of highways were built and national road capacity grew by only $1-2 \%$ per year, in the future the construction sector will play a role in meeting economic needs in building at least $500 \mathrm{~km}$ of highways per year, and increasing 5\% per year in national road capacity (Damuri, 2017). Thus, the construction sector will contribute to reducing the current open unemployment rate by $5.7 \%$ and poverty to below $10 \%$.

Construction projects require resource management to achieve the above objectives. Appropriate resource management in construction projects can result in substantial time and cost savings (Shehata and El-Gohary, 2011). Labour productivity in the construction industry is very important considering construction is a labour-intensive industry. Abdul Rahman, et al. (2013) stated that inefficient management of construction resources can result in low productivity.

The success of a project is measured by its success in achieving cost, quality, time, and work security in accordance with the plan (Westover, et al., 2010). To answer the needs so that the project can be completed and meet the objectives, optimal planning and control is needed in terms of implementation management. Labour productivity determines the successful implementation of the construction project schedule (Robles, et al., 2014; Hickson and Ellis, 2014). It will affect the suitability of the construction schedule planning with the progress of construction work in the field, where the construction schedule with the progress of the construction work will affect the duration and cost of the project.

By looking at the importance of labour productivity in construction projects, this study aims to analyze labour productivity in construction projects on one campus in the city of Palembang, Indonesia. The campus is Universitas Islam Negeri Raden Fatah Palembang. The study was conducted by observing the activities of labours in two conditions, namely during and after the month of Ramadan. Because the month of Ramadan requires Muslim labours to fast, the study is interesting to compare the labour productivity during and after the month of Ramadan. 


\section{LITERATURE REVIEW}

\section{Labour Productivity}

Productivity is generally used to describe how the relationship between output and input that is related in the production process (Liou, 1986; Gerek, et al., 2015). In the construction industry, productivity is often referred to as labour productivity (Hajikazemi, et al., 2017). This is defined as a unit of work that is housed or discharged per hour (Halligan, et al., 1994). Labour productivity usually associates labour in terms of labour cost with the quantity of output produced (Liou and Borcherding, 1986). According to (Dozzi and AbouRizk, 1993) traditionally productivity is the ratio of inputs to outputs, where inputs refer to related sources and outputs as tangible outputs in creating economic value. While following Shehata and El-Gohary (2011) the definition of productivity is the ratio of income to real hours.

In contrast, Song and AbouRizk (2008) are expressed as the ratio of the quantity of output to the quantity of input, and in guidance, productivity can be measured at different levels according to the objectives to be achieved. According to the American Association of Cost Engineers productivity is a measure of relative efficiency, good or bad as compared to the norms or norms (Haas, et al., 2000). Productivity is about profit and performance. The term profit is related to productivity as it looks at the relationship between profit as well as through the relationship between output and input (Tangen, 2005). But the relationship in profit is monetary because it influences the price factor. There is a difference between productivity, profit and performance in a project. Benefits take into account monetary, productivity-related effects of the actual processes that occur between pure physical phenomena. However, the biggest productivity factor is performance. Performance is a larger concept that involves the economic and operational aspects of the industry (Pekuri, et al., 2011).

\section{Construction Labour Productivity}

Construction labour productivity (CLP) is related to the efficient use of labour in construction projects, which means to achieve efficiency in construction projects as measured by labour productivity, through a complex process, where measurements are made by changing existing inputs such as labour, materials, equipment, etc. for work-produced outputs or project products (Tsehayae and Fayek, 2014). CLP research as it is known has been widely practiced in many countries around the world, so from previous studies CLP has been grouped into three levels namely industry, project and activity (Yi and Chan, 2014).

In the labour-intensive construction industry and for efficiency, CLP is more precisely measured at the activity level, because at the level of activity CLP size is linked through the process of converting input to output (Tsehayae and Fayek, 2016), in this case CLP is defined as the number of working hours used (input) for installed output. In this case the amount produced (Yi and Chan, 2014). CLP analysis and modeling are performed for the benefit of CLP optimization, using CLP analysis and modeling can easily describe the process of converting or converting input variables into outputs and affecting CLP efficiency, so in order to analyze CLP the relationship between the three variables involved in CLP model, there are input, process and output (Tsehayae and Fayek, 2016).

Keep in mind that since labour costs in a construction project make up a large one-third to one-half of the total cost of the project, the productivity of construction labours has a very significant impact on the success of the project, especially on the cost and ultimately of project profitability (Tsehayae and Fayek, 2014). To achieve success a project must be supported by the proper and efficient CLP. To achieve this, they also need to be supported by project teams / teams who have the ability to understand, identify project contexts and accurately predict CLPs, as CLPs are key in controlling project costs and project success. In a construction project, effective use of skilled labour should be given priority, as skilled resources are rarely / never found (Dai and Goodrum, 2012).

By analyzing and modeling CLPs for the sake of project success, especially in terms of cost, what needs to be done is to identify the complex key parameters that influence CLP where these key parameters still depend on context, factors and practices (Tsehayae and Fayek, 2014). In this regard, identifying key parameters that are influential and relevant to the project or context under review is not an easy task. Determining these parameters that are considered to be influential and dependable on the project under review requires careful, careful and complex consideration, leveldependent and context-dependent (Tsehayae and Fayek, 2014). The parameters in the CLP itself are subject to many factors and good practice objectively and subjectively, including crew size, weather, image quality, foreman skills, availability of materials and equipment on site, location of material placement, supervisory capacity, absence and so on. Parameters in CLP are used for identification and analysis purposes, the final result achieved in CLP is efficiency, so that if efficiency in CLP is achieved then project management is classified as successful and project profitable, and the main purpose of the project is cost, quality and time can be met.

\section{METHOD}

This study measures the productivity of construction workforce with the Work Sampling Method. Work Sampling Method is a technique where many instant observations are made in the time period of a group of labours, machines or processes.

In this research, productivity rating is conducted, where the activities of a labour are classified into three, namely: effective, essential contributory, and ineffective. Effective 
work is work where the labour's activities are directly related to the construction process that directly plays a role in the final output. Examples are the work of installing bricks, plastering walls, and others. Essential contributory work is an activity that does not directly influence the final result, but is generally needed in carrying out an operation. Examples are reading drawings, cleaning workplaces, carrying materials, etc. Ineffective work is the activity of unemployed or labours do something that is not directly related to the work being done. Examples are labours who just walk around without carrying anything, doing work that is not according to procedures, chatting, etc.

Observations in the field are carried out as follows: (a) the observer completes himself, minimum with paper and stationery, (b) the observer surrounds the field, then records the labours met and classifies them into one type of activity (effective, essential contributory, or ineffective work), and (c) Observations are made by following the work sampling principles outlined above.

After observations have been made, the number of labours is calculated in each type of activity. To calculate the level of effectiveness (productivity) of labours, the Labour Utilization Rate (LUR) approach is used. LUR can be used to find out how effective (productive) labours are on a project, but it cannot explain why the value is low or high. In other words LUR cannot show the factors that cause the low or high productivity of labours.

\section{FINDINGS AND ANALYSIS}

This study measures construction labour productivity in building projects at the Universitas Islam Negeri Raden Fatah Palembang. There are ten observational works, namely electrical, bastion cleaning, stirring, formwork installation, light brick wall installation, beam and column cleaning, wall plastering, steel roofing, flooring, and scafolding. Observations were made on projects carried out during the month of Ramadan and after the month of Ramadan. During the month of Ramadan, the number of labours observed was 54 labours, while in the month after Ramadan, the number of labours observed was 53 labours.

When compared between the two observations, productivity in the month after Ramdhan shows a higher value compared to labour productivity in the month of Ramdhan. Table 1 shows that labour productivity in the month after Ramadan is higher compared to labour productivity during the month of Ramadan for almost all types of work, except for the installation of formwork and construction of beams and columns.
Table 1. Result of Construction Labour Productivity

\begin{tabular}{|c|c|c|c|c|}
\hline Works & $\begin{array}{l}\text { Productivi } \\
\text { ty in the } \\
\text { month of } \\
\text { Ramdhan }\end{array}$ & $\begin{array}{l}\text { Un } \\
\text { it }\end{array}$ & $\begin{array}{l}\text { Productivity in } \\
\text { the month after } \\
\text { Ramadan }\end{array}$ & Unit \\
\hline Electrical & 2,73 & $\mathrm{M}^{\prime}$ & 4,65 & $\mathrm{M}^{\prime}$ \\
\hline Bastion cleaning & 11,50 & $\mathrm{Kg}$ & 12,59 & $\mathrm{Kg}$ \\
\hline Stirring & 8,31 & $\mathrm{Kg}$ & 30,29 & $\mathrm{Kg}$ \\
\hline Formwork & & M & & \\
\hline installation & 12,92 & 2 & 12,08 & M2 \\
\hline Light brick wall & & M & & \\
\hline installation & 2,55 & 2 & 2,60 & M2 \\
\hline $\begin{array}{l}\text { Beam and column } \\
\text { cleaning }\end{array}$ & 12,97 & $\begin{array}{l}\mathrm{Kg} \\
\mathrm{M}\end{array}$ & 10,71 & $\mathrm{Kg}$ \\
\hline Wall plastering & 7,58 & 2 & 8,82 & M2 \\
\hline Steel roofing & 13,33 & $\begin{array}{l}\mathrm{Kg} \\
\mathrm{M}\end{array}$ & 16,57 & $\mathrm{Kg}$ \\
\hline Flooring & 4,50 & 2 & 5,20 & M2 \\
\hline Scafolding & 3,64 & Set & 5,00 & Set \\
\hline
\end{tabular}

The difference in labour productivity is seen to be very significant in the type of work in the form of clearing of stirrups. During the month of Ramadan, productivity shows 8.31 per $\mathrm{kg}$, while in months after Ramadan show a very significant difference because it shows the number 30.29 per $\mathrm{kg}$. in other types of work, although showing differences but not too significant.

In each type of work, observations were made on activities related to the number of observations that varied between one type of work with another type of work. Of the ten types of work performed, the most observations of activity were carried out on plastering walls with 2723 observations. The type of work with the least total observations is the type of work in the form of making floors with 470 observations.

Table 2. Percentage of Productive, Contributory and Ineffective Activity During Ramadan

\begin{tabular}{|c|c|c|c|c|c|c|c|}
\hline \multirow[t]{2}{*}{ Works } & \multirow{2}{*}{$\begin{array}{l}\text { Total } \\
\text { Observ } \\
\text { ation }\end{array}$} & \multicolumn{2}{|c|}{$\begin{array}{l}\text { Productiv } \\
\text { e }\end{array}$} & \multicolumn{2}{|c|}{$\begin{array}{l}\text { Contributor } \\
\mathrm{y}\end{array}$} & \multicolumn{2}{|c|}{ Ineffective } \\
\hline & & $\begin{array}{l}\text { To } \\
\text { tal }\end{array}$ & $\%$ & $\begin{array}{l}\text { Tota } \\
1\end{array}$ & $\%$ & $\begin{array}{l}\text { Tota } \\
1\end{array}$ & $\%$ \\
\hline & 1.603 & 11 & 71,4 & 286 & 17,8 & 171 & 10,6 \\
\hline Electrical & & 46 & 9 & & 4 & & 7 \\
\hline $\begin{array}{l}\text { Bastion } \\
\text { cleaning }\end{array}$ & 1.020 & $\begin{array}{l}76 \\
1\end{array}$ & $\begin{array}{l}74,6 \\
1\end{array}$ & 160 & $\begin{array}{l}15,6 \\
9\end{array}$ & 99 & 9,71 \\
\hline & 1.195 & 86 & 72,5 & 185 & 15,4 & 143 & 11,9 \\
\hline Stirring & & 7 & 5 & & 8 & & 7 \\
\hline Formwor & 1.620 & 12 & 74,6 & 209 & 12,9 & 202 & 12,4 \\
\hline
\end{tabular}




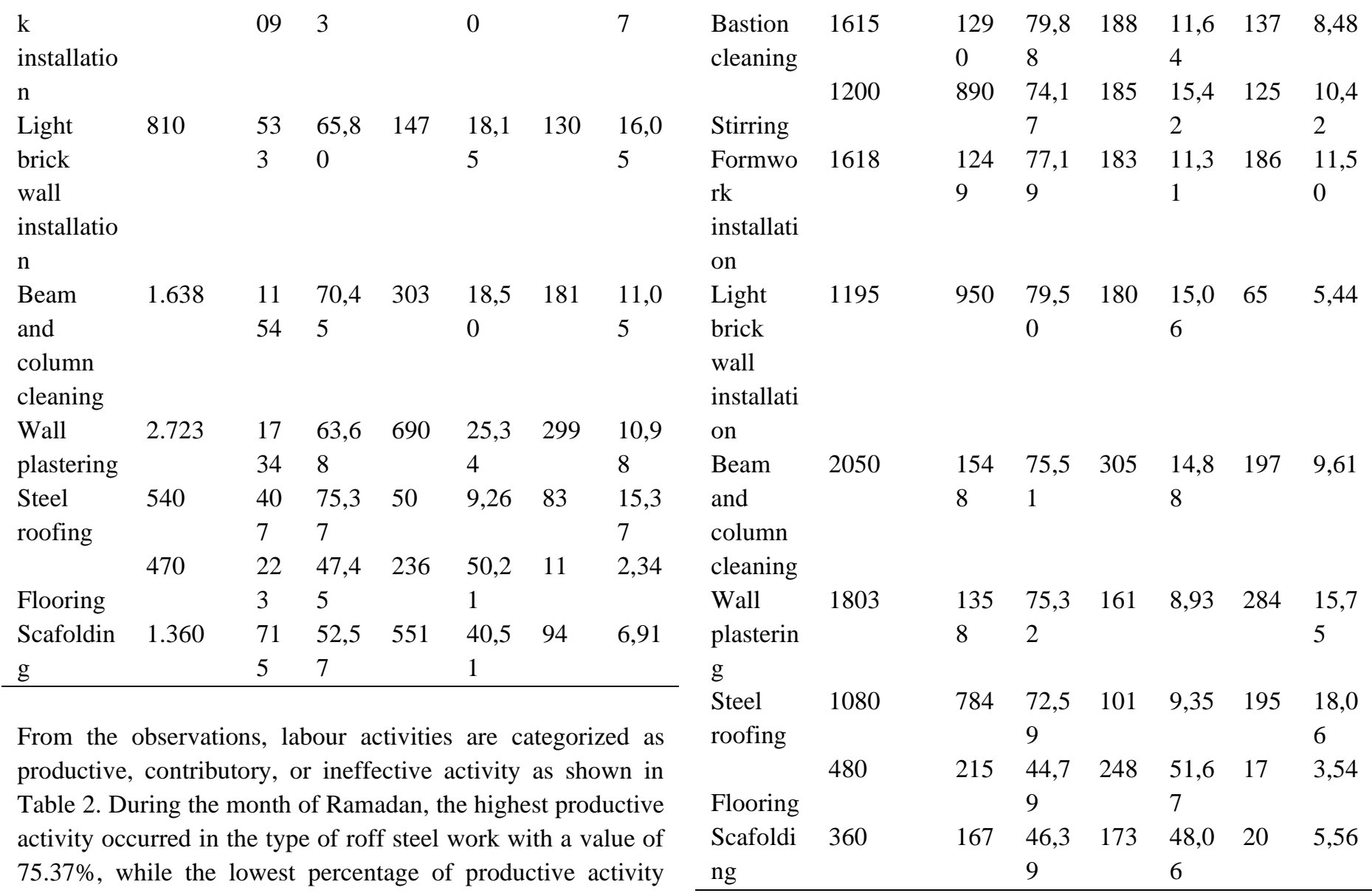
occurred in the flooring work with a value of $47.45 \%$. Then, the highest contributory activity is seen in scafolding works with a value of $40.51 \%$, while the lowest is roof steel work with a value of $9.26 \%$. As for the highest ineffective activity related to light brick wall installation work with a value of $16.05 \%$, while the lowest is the making floors with a value of $2.34 \%$

At the time after Ramadan, the highest productive activity occurred in the baston cleaning work with a value of $79.88 \%$, while the lowest percentage of productive activity occurred in the work of making floors with a value of $44.79 \%$ (see table 3 ). Then, the highest contributory activity was seen in flooring work with a value of $51.67 \%$, while the lowest was roof steel work with a value of $9.35 \%$. The highest ineffective activity related to roof steel work with a value of $18.06 \%$, while the lowest is the manufacture of floors with a value of $3.54 \%$.

Table 3. Percentage of Productive, Contributory and Ineffective Activity After Ramadan

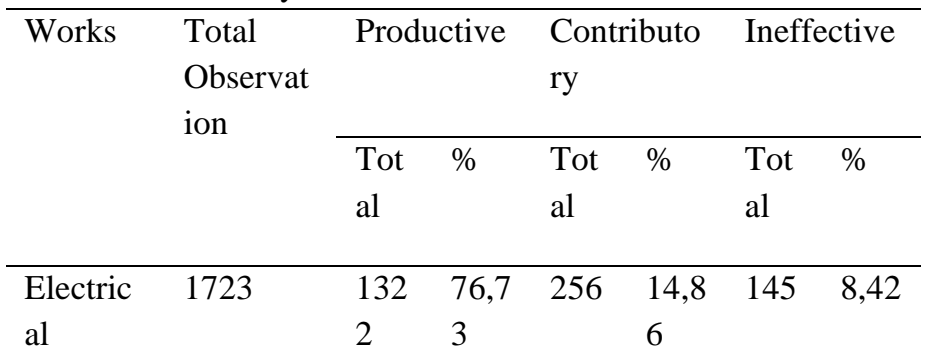

This study conducted LUR calculations for all work by first recapitulating data. The number of effective, contributory, ineffective works is added according to their classification. Then the total value of each work is used for LUR calculation. LUR is the percentage obtained from the sum of effective work added by $1 / 4$ essential contributory work, then dividing the sum by the total observations. LUR values greater than $50 \%$ indicate that the workforce is working effectively. The result of LUR still has limitations, one of which is the unknown factors that cause the low productivity of labours.

This research calculates LUR for all work both during Ramadan and after Ramadan. Recapitulation of LUR can be seen in table 4.

Table 4. Recapitulation of LUR

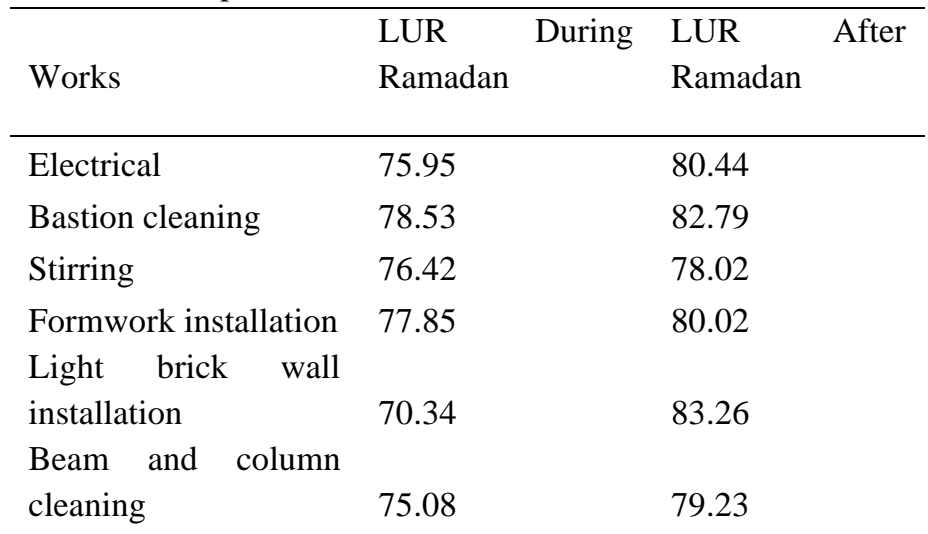




\begin{tabular}{lll} 
Wall plastering & 70.01 & 77.57 \\
Steel roofing & 77.69 & 74.93 \\
Flooring & 60.00 & 57.71 \\
Scafolding & 62.70 & 58.40 \\
\hline
\end{tabular}

At the time of Ramadan, the highest LUR occurred in the bastion cleaning work with a value of $78.53 \%$, while the lowest occurred in the flooring work with a percentage of $60 \%$. After Ramadan, the highest LUR occurred in light brick wall installation work with a percentage of $83.26 \%$, while the lowest occurred in flooring with a percentage of $57.71 \%$.

\section{CONCLUSION}

Construction labour productivity shows that labours do work effectively. LUR calculation results that show values above $50 \%$ for all types of work confirm this. However, construction labour productivity still needs to be improved, especially in flooring and scafolding works. By also analyzing construction labour productivity in two conditions, namely during and after the month of Ramadan, this study concludes that labour productivity in months other than Ramadan is higher than labour productivity during Ramadan.

\section{ACKNOWLEDGMENT}

This research supported by Ministry of Higher Education using research funds KK-2018-013. We thank our colleagues from Universiti Kebangsaan Malaysia (UKM), who provided insight and expertise that greatly assisted the research.

\section{REFERENCES}

[1]. Abdul Rahman, Ismail \& Memon, Aftab \& Abd Karim, Ahmad. (2013). Relationship between Factors of Construction Resources Affecting Project Cost. Modern Applied Science. 7. 67-75. 10.5539/mas.v7n1p67.

[2]. Dai, Jiukun \& Goodrum, Paul. (2012). Generational differences on craft workers' perceptions of the factors affecting labour productivityThis paper is one of a selection of papers in this Special Issue on Construction Engineering and Management.. Canadian Journal of Civil Engineering. 39. 10.1139/12012-053.

[3]. Dozzi, S. P. \& AbouRizk, S. M. (1993). Productivity in Construction. doi:10.1061/(ASCE)CO.1943-7862.0001138.

[4]. Durdyev, Serdar \& Ismail, Syuhaida. (2012). Role of the construction industry in economic development of Turkmenistan. Energy Education Science and Technology Part A: Energy Science and Research. 29. 883-890.

[5]. Gerek, İ. H., Erdis, E., Mistikoglu, G. \& Usmen, M. (2015). Modelling masonry crew productivity using two artificial neural network techniques. Journal of Civil Engineering and Management. 21(2). 231238. doi:10.3846/13923730.2013.802741

[6]. Hajikazemi, S., Andersen, B. \& Langlo, J. A. (2017). Analyzing electrical installation labour productivity through work sampling. International Journal of Productivity and Performance Management. 66(4). doi:10.1108/IJPPM-06-20160122

[7]. Haas, Carl \& Borcherding, John \& ALLMON, ERIC. (2000). U.S. Construction Labour Productivity Trends, 1970-1998. Journal of Construction Engineering and Management. 126. 10.1061/(ASCE)0733-9364(2000)126:2(97).

[8]. Halligan, D.W., Demsetz, L.A., Brown, J., \& Pace, C.B. (1994). Action-Response Model and Loss of Productivity in Construction. Journal of Construction Engineering \& Management. 120(1). 47-64.

[9]. Liou, F.S. (1986). Work sampling can predict unit rate productivity. Journal of Construction Engineering \& Management. 112(1). 90-103.

[10]. Liou, F. \& Borcherding, J. D. (1986). Work Sampling Can Predict Unit Rate Productivity. Journal of Construction Engineering and Management. 112(1). 90-103. doi:10.1061/(ASCE)0733-9364(1986)112:1(90).

[11]. Hickson, Brent \& Ellis, Leighton. (2014). Factors affecting Construction Labour Productivity in Trinidad and Tobago. The Journal of the Association of Professional Engineers of Trinidad and Tobago. 42(1). 4-11.

[12]. Khurriah, Hanifatul \& Istifadah, Nurul. (2019). The Role of Infrastructure in Indonesia's Economic Growth. International Journal of Advances in Scientific Research and Engineering. 5. 215-222. 10.31695/IJASRE.2019.33447.

[13]. Momade, Mohammed Hamza \& Shahid, Shamsuddin \& Hainin, Mohd Rosli \& Nashwan, Mohamed. (2019). Construction Labour Productivity: Review of Factors Identified. International Journal of Construction Management. 10.1080/15623599.2019.1627503.

[14]. Ofori, George. (2019). Construction in Developing Countries: Need for New Concepts. Journal of Construction in Developing Countries. 23. 1-6. 10.21315/jcdc2018.23.2.1.

[15]. Pekuri, Aki \& Haapasalo, Harri \& Herrala, Maila. (2011). Productivity and performance management - Managerial practices in the construction industry. International Journal of Performance Measurement. 1. 39-58. 
[16]. Robles, G. \& Stifi, Ahmed \& Ponz-Tienda, José \& Gentes, S.. (2014). Labour Productivity in the Construction Industry -Factors Influencing the Spanish Construction Labour Productivity-. International Journal of Civil, Architectural, Structural and Construction Engineering. 8. 9991008.

[17]. Shehata, Mostafa \& El-Gohary, Khaled. (2011). Towards improving construction labour productivity and projects' performance. Alexandria Engineering Journal. 50. 321-330. 10.1016/j.aej.2012.02.001.

[18]. Song, L. \& AbouRizk, S. M. (2008). Measuring and Modeling Labour Productivity Using Historical Data. Journal of Construction Engineering and Management 134(10): 786-794. doi:10.1061/(ASCE)0733-9364(2008)134:10(786)

[19]. Tangen, Stefan. (2005). Demystifying productivity and performance. International Journal of Productivity and Performance Management. 54. 3446. 10.1108/17410400510571437.

[20]. Tsehayae, A. A. \& Robinson Fayek, A. (2014). Identification and comparative analysis of key parameters influencing construction labour productivity in building and industrial projects. Canadian Journal of Civil Engineering. 41. 878891. doi:10.1139/cjce-2014-0031

[21]. Tsehayae, Abraham \& Fayek, Aminah. (2016). Developing and Optimizing Context-Specific Fuzzy Inference System-Based Construction Labour Productivity Models. Journal of Construction Engineering and Management. 142. 04016017. 10.1061/(ASCE)CO.1943-7862.0001127.

[22]. Wells, Jill. (1985). The role of construction in economic growth and development. Habitat International. 9(1). 55-70.

[23]. Westover, Jonathan \& Westover, Andrew \& Westover, L.. (2010). Enhancing long-term worker productivity and performance. International Journal of Productivity and Performance Management. 59. 372-387. 10.1108/17410401011038919.

[24]. Yi, Wen \& Chan, Albert. (2014). Critical Review of Labour Productivity Research in Construction Journals. Journal of Management in Engineering. $30 . \quad 214-225 . \quad 10.1061 /(A S C E) M E .1943-$ 5479.0000194. 